\title{
História de alguns melancólicos que tiveram estranhas imaginações*
}

André Du Laurens

Eu já descrevi amplamente os acidentes que acompanham os verdadeiros melancólicos e investiguei as causas de todas as suas variedades. É necessário neste capítulo, para o deleite do leitor, propor alguns exemplos de melancólicos que tiveram as mais bizarras e loucas imaginações. Alguns tomarei emprestado dos gregos, árabes e latinos e outros que eu mesmo vi.

Galeno, no terceiro livro do Dos lugares afetados, conta três ou quatro casos notáveis. Houve um melancólico que pensava ter se tornado um vaso, e pedia a todos que vinham vê-lo que não se aproximassem muito, por medo que o quebrassem. Outro imaginava ter se tornado um galo, cantava como um galo, batia seus braços como os galos batem suas asas. Outro melancólico queixava-se de uma pena extrema, maior que a de Atlas, pois o céu podia tombar sobre ele.

Aécio menciona um melancólico que acreditava não ter a cabeça e dizia a todos que o haviam decepado por causa de suas tiranias. Ele foi curado por meio de um artifício sutil de um mé-

* Sétimo capítulo do Discours de la conservation de la vue, des maladies melancholiques, des catarrhes, \& de la vieillesse. Paris: Jamet Mettayer, 1597, p. 137141. Tradução de Paulo José Carvalho da Silva. 
dico, chamado Filodemo, que colocou uma espécie de capacete de ferro bem pesado sobre sua cabeça, levando-o a admitir que tinha dor de cabeça diante dos assistentes que, então, lhe disseram: o senhor tem, portanto, uma cabeça; o que o liberou de sua falsa imaginação.

Alexandre de Trales escreve ter visto uma mulher que acreditava ter devorado uma serpente. Ele a curou fazendo-a vomitar e colocando uma serpente de verdade na bacia. Eu li que um jovem estudante foi surpreendido por uma estranha imaginação. Ele se pôs a fantasiar que seu nariz havia crescido e alongado tanto que ele não ousava se mexer do lugar, de modo que ele pudesse chocar-se com algum lugar: tanto mais tentavam dissuadi-lo, mais ele se obstinava. Enfim, o médico pegou um grande pedaço de carne e dizendo que iria tratar o menino, fez um pequeno corte em seu nariz e fingiu ter extraído aquele pedaço de carne, fazendo-o crer que havia cortado seu grande nariz.

Um sábio, ao ver um crocodilo, foi tomado por tamanho pavor que esqueceu tudo o que sabia e ficou com a permanente impressão de que havia perdido um braço e uma perna. Viu-se vários melancólicos que acreditavam estarem mortos e se recusavam a se alimentar. Os médicos usaram dos seguintes artifícios para fazê-los comer: eles fizeram alguns assistentes deitarem-se próximo aos enfermos e os instruíram para fingirem-se de mortos, mas comerem a comida que lhes era colocada em suas bocas. Por meio dessa astúcia, persuadiram os melancólicos que os mortos comem tanto quanto os vivos.

Viu-se, não faz muito tempo, um melancólico que se dizia o mais miserável do mundo porque ele não era nada. Havia um grande senhor que pensava ser de vidro, mas essa era a única imaginação perturbada que ele apresentava, pois discorria maravilhosamente bem sobre todas as outras coisas. Ele ficava normalmente sentado e tinha prazer em receber a visita de seus amigos, entretanto pedia para que não se aproximassem dele.

(...) Areteu, no primeiro livro das doenças crônicas, afirma ter visto um melancólico que pensava ser de tijolos e se recusava a beber qualquer líquido, temendo desmanchar-se. Outro pensava ter os pés de vidro e não ousava caminhar com medo de quebrá-los. Um padeiro pensava ser de manteiga e não podia aproximar-se do fogo ou de seu forno, tamanho seu medo de derreter.

A mais engraçada imaginação que eu já li é de um nobre de Siena que resolveu nunca mais urinar, preferindo morrer, porque ele imaginava que se urinasse toda a cidade se inundaria. Mesmo os médicos dizendo que nem o corpo dele, nem os corpos de mais cem mil pessoas seriam capazes de molhar sequer uma simples casa da cidade, não conseguiram desviá-lo dessa louca imaginação. Enfim, considerando sua obstinação e o perigo para sua vida, encontraram uma engraçada invenção. Eles colocaram fogo numa casa próxima, fizeram tocar todos os 
sinos da cidade, pediram aos assistentes que gritassem "fogo", "fogo", e a outros que pedissem socorro. Ao nobre enfermo disseram que o único modo de salvar a cidade seria se ele urinasse imediatamente para apagar o incêndio. O pobre melancólico, que se continha por medo de prejudicar a cidade, crendo-a em perigo, urinou até esvaziar sua bexiga e foi dessa forma salvo.

No que diz respeito aos que se crêem reis, imperadores, papas e cardinais, essas são loucuras comuns. Eu preferi relatar os casos mais raros.

Eis o que é da melancolia que toma o cérebro, que é causada por uma condição fria e seca, sem matéria, ou com matéria. Ela segue, algumas vezes, as enfermidades quentes do cérebro, como o frenesi e as febres ardentes, quando o rosto se torna vermelho. Avicena observa que os gagos, os que possuem os olhos agitados e as veias amplas, são mais sujeitos à melancolia. Finalmente, a tristeza, o medo, as profundas meditações, o uso de carnes pesadas e melancólicas causam freqüentemente essa enfermidade.

ANdré Du Laurens (1558-1609)

Importante médico francês, ocupou os cargos de primeiro médico do rei Henri IV e de chanceler da Universidade de Montpellier. 